\title{
Change Detection of Urban Land Use and Urban Expansion Using GIS and RS, Case Study: Zanjan Province, Iran
}

\author{
Mojtaba Pirnazar ${ }^{1}$, Kaveh Ostad-Ali-Askari ${ }^{2}$, Saeid Eslamian ${ }^{3}$, Vijay P. Singh ${ }^{4}$, Nicolas R. \\ Dalezios $^{5}$, Mohsen Ghane ${ }^{6}$,Zahra Qasemi ${ }^{7}$ \\ ${ }^{I}$ Department of Remote Sensing, Tabriz University, Tabriz, Iran \\ ${ }^{2 *}$ Department of Civil Engineering, Isfahan (Khorasgan) Branch, Islamic Azad University, Isfahan, Iran \\ ${ }^{3}$ Department of Water Engineering, Isfahan University of Technology, Isfahan, Iran \\ ${ }^{4}$ Department of Biological and Agricultural Engineering \&Zachry Department of Civil Engineering, Texas A \\ and M University, 321 Scoates Hall, 2117 TAMU, College Station, Texas 77843-2117, U.S.A. \\ ${ }^{5}$ Laboratory of Hydrology, Department of Civil Engineering, University of Thessaly, Volos, Greece \& \\ Department of Natural Resources Development and Agricultural Engineering, Agricultural University of \\ Athens, Athens, Greece. \\ ${ }^{6}$ Civil Engineering Department, South Tehran Branch, Islamic Azad University, Tehran, Iran \\ ${ }^{7}$ Department of Remote Sensing, Yazd Branch, Islamic Azad University, Iran
}

*Corresponding Author: Dr. Kaveh Ostad-Ali-Askari, Department of Civil Engineering, Isfahan (Khorasgan) Branch, Islamic Azad University, Isfahan, Iran.Emails: Koa.askari@khuisf.ac.ir, Kaveh.oaa2000@gmail.com

\begin{abstract}
Accurate data and timely information regarding the existing land-uses is needed to manage the natural landscapes effectively. The information related to land-use changes constitutes the basic element in management of natural resources. In fact, the awareness about patterns of land-use changes is conductive of ecosystem toward balance. Therefore, the need to detect, plan and predict such changes in an ecosystem is of great importance. In order to discover these changes, the application of multi-temporal remote sensing data $(R S)$ and geographical information system (GIS) provides the possibility of valuable analysis. In this paper, two images, i.e. ETM+ 2002 and OLI 2015 were used for Zanjan city. To map the pattern of changes, at first the coordinates of two images were integrated, andafter the atmospheric corrections, the considered area was classified to four classes including residential areas, road network, vegetation and other regions using the maximum likelihood method. Then,Post classification and overlapping methods were used to detect changes. The results show that the urban expansion has increased during 13 years. The expansion of Zanjan City has been inclined more toward north and north -west affecting the barren lands, while the garden lands in the south has been less influenced by urban expansion.
\end{abstract}

Keywords: Change detection, Land-use, Remote sensing, GIS, Landsat, Zanjan city

\section{INTRODUCTION}

The cities accommodate various activities and multiple functionalities where any changes in them are inevitable. In the past fifty years, the spatial organization of the cities and their original structure has changed dramatically, and thus the cities are segmented to different regions, each involving a particular activity. The rapid growth of the cities and urbanization is consequence of industrialization and the changes made in technology. Change detection includes application of multi-temporal data in order to identify the regions in which land-use has changed during different periods of imagery. These changes may be result of short term cover changes such as snowfall, floods, or changes in land-use like urban development and conversion of agricultural lands into residential and industrial purposes (Rabiei et al, 2004). There are different methods to obtain extent and severity of land-use changes, from Principal Component Analysis to Spectro-temporal Classification and using fuzzy logic etc. In places where landscapes, in particular urban land-uses are under change due to human activities and natural processes like erosion, using the geographical information system (GIS), remote sensing and data processing can be helpful in analyzing the changes and extent of them [1-14]. 


\section{Problem Statement}

The world we live in is changing all the time and it can be said that as result of such revolutions some phenomena are disappeared or replaced by new ones. We can see many of these changes if we take a glance at our surrounding. The cities are expanded, desertification and soil erosion is occurred, the forests are removed or expanded and the farms are converted to barren lands; in addition, flood and heavy rainfalls lead to destruction of farms, and the phenomena such as marine transgression and regression are other examples of such changes that are occurring permanently in the world around us.

\section{RESEARCH IMPORTANCE}

Today land-use change maps with high accuracy can become an essential tool to design and manage the landscape and thus such studies are required for different cities. In last four decades, land - use changes in Iran have occurred rapidly and sometimes in negative direction so that intensified the trend of land destruction. Since the land-use change is take place in large scale, therefore, the application of traditional methods in harvest and land measurement requires spending extra time and money;even in impassable places these methods are not applicable. Using satellite images are of crucial importance due to their critical features including vast field of view, cost effectiveness, using different parts of electromagnetic spectra to detect characteristics of phenomena, short recurrence period, possibility of automatic analysis, rapid analysis as well as possibility of regional monitoring (Jensen, 2005). Remote sensing data are characterized by repeated imagery in short intervals, extended land cover surface detected by sensors and spectral and spatial classification of data and thus are good instrument to assess the land cover changes. Today, the advance in remote sensing techniques and GIS has provided substantial opportunities to monitor and manage the rapid growth of cities [15-35].

\section{RESEARCH OBJECTIVE}

The goal of this research is to discover and express the urban land-use changes and urban expansion of Zanjan City during a 13-years interval.

\section{BACKGROUND}

\subsection{Literature Review}

Gong (1993) conducted a research to detect changes in part of Ontario, Canada, integrating principal component analysis and fuzzy procedures and expressed the change information from different image channels in a single-image channel.

Moreover, Kong et al (2004) in a paper called 'Spatial-temporal gradient analysis of urban green spaces in Jinan, China' created categorical maps of urban space using 1989 spot images, 1989 landsat image, 2004 spot images, topographic maps (1:10000) and census data, then applied spatial analysis techniques for quantification of urban green space pattern. Therefore, they proposed a new method to study patterns of spatial - temporal changes in urban green space by integrating remote sensing method, GIS, landscape parameters and gradient analysis.

In Iran, Kouhkan (2002) investigated change detection in urban lands of Mashhad during 1987-1998 using fuzzy theory method.

In another study, Jafari et al (2010) studied land-use changes in Kashan region during a 15-year interval and concluded that land cover/use changes resulted from human activities would be an important matter in regional and developmental planning.

Jalili et al (2013) in a paper called 'change detection of land cover/use in Zagros forests using satellite images and GIS during 1989-2010; case study: Dehdez lands' concluded that among the effective factors on land-use change of Dehdez forests, the distance from the village had the most important effect on change patterns [36-48].

Furthermore, Kolahashemi et al (2013) in a research called 'change detection of land-use changes using maximum likelihood method and RS-GIS techniques' studied the Babavali basin in Siahkal region during a 13-years period and obtained results of land-use classification in 2000 and 2013. The verification of results against land realities and field study indicatestotal validity of 0.89 and 0.88 as well as Kappa coefficient equal to 0.88 and -.87 in2000 ETM+ images and 2013 landsat 8 images, respectively. 
Change Detection of Urban Land Use and Urban Expansion Using GIS and RS, Case Study: Zanjan Province, Iran

\section{STUdy AREA}

Zanjan city is located in east part of Zanjan province alongside the Tehran - Tabriz highway, above 1663 meters from sea surface. This city is located in $48^{\circ} 14^{\prime}-48^{\circ} 44^{\prime} \mathrm{E}$ and $36^{\circ} 34^{\prime \prime}-36^{\circ} 46^{\prime} \mathrm{N}$ surrounded by altitudes in north, north-east, south and south-west. Tehran - Tabriz highway passing within Zanjan is south east - north westward along the Tehran - Tabriz railway. The development of this city is such that it has affected north parts of this region and by moving toward the north, northwest and northeast the height is increased so that it leads to altitudes in north and north east.

Overall it can be said that during the urban expansion, texture and urban vision of Zanjan has been influenced by topographic qualities particularly the altitudes in north and south of the city; in addition, urban location has been along Zanjan Rood River. Figure (1) presents the location of Zanjan city in Iran, province and county [49-65].

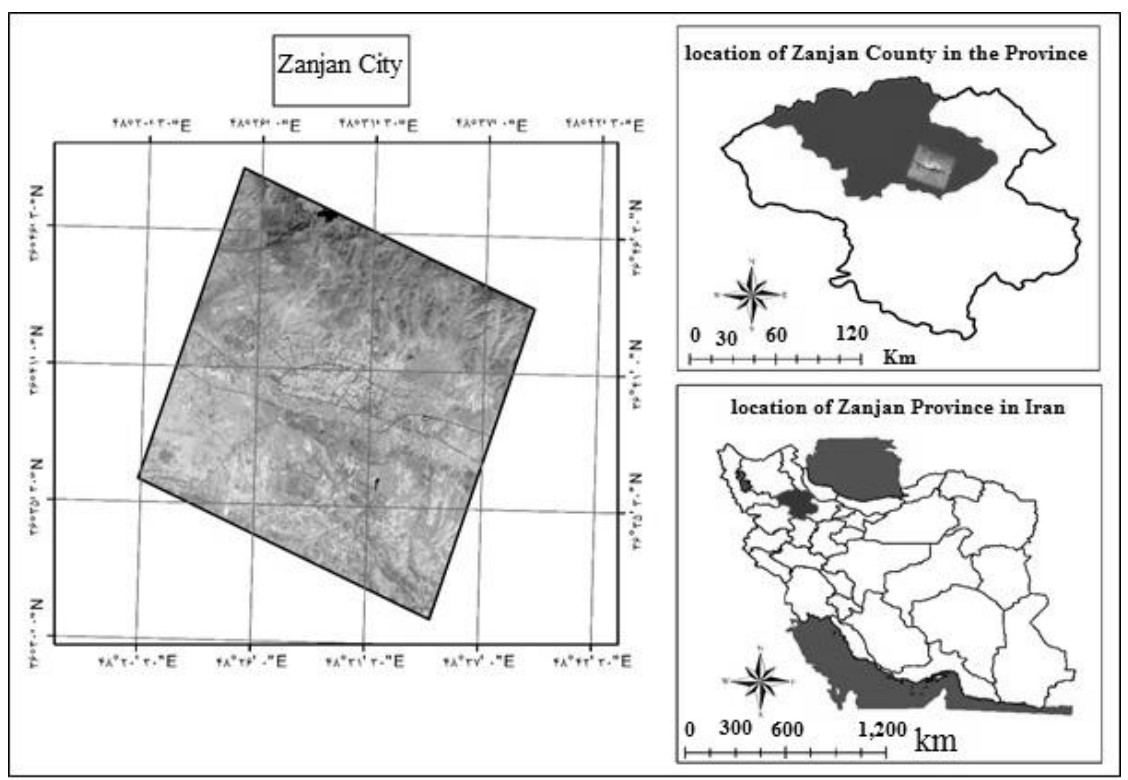

Figure1. Geographical location of study area (Zanjan City)

\section{Material And Method}

\subsection{Characteristics of Satellite Image}

\subsection{Land sat Satellite}

The first civil earth-observing satellite called Landsat 1 was launched in 1972. After that, four other satellites from Landsat series have launched gradually. Landsat satellites originally named 'Earth Resources Technology Satellite' or ERTS consist of four series sensors including MMS, RBV, TM, ETM+, TIRS and OLI each with unique features that are optical - mechanical sensors. The last series of these satellites called Landsat 8 was launched in 2013. The orbit of these satellites has been selected such that they cross the equator approximately at 10:00 a.m local time. They cover a 185kilometer swath in each pass and image the earth every 16 days. The missions and sensors of these satellites are discussed below (Pirnazar \& Zandkarimi, 2014:28). a summary of the information related to Landsat satellites is presented in table 1.

Table1. The information related to Landsat series

\begin{tabular}{|l|l|l|l|}
\hline Satellite & Launch & Status/ mission termination & Sensors \\
\hline 1 & 1972 & 1978 & MSS, HBV \\
\hline 2 & 1975 & 1982 & MSS, HBV \\
\hline 3 & 1978 & 1983 & MSS, HBV \\
\hline 4 & 1982 & 2001 & MSS, TM \\
\hline 5 & 1984 & 2013 & MSS, TM \\
\hline 6 & 1983 & Failed to reach orbit & ETM \\
\hline 7 & 1999 & Loss of operation & ETM+ \\
\hline 8 & 2013 & Operational & OLI, TIRS \\
\hline
\end{tabular}


Change Detection of Urban Land Use and Urban Expansion Using GIS and RS, Case Study: Zanjan Province, Iran

The images provided by these satellites have various functions with respect to their coverage band and are available to download with no charge. Table 2 presents the information related to wavelength of bands and spatial resolution.

Table2. The information related to wavelength and spatial resolution of Landsat bands

\begin{tabular}{|c|c|c|c|c|c|}
\hline Satellite & Sensor & Channel & Band & Wavelength & $\begin{array}{l}\text { Spatial } \\
\text { resolution }(\mathrm{m})\end{array}$ \\
\hline $\begin{array}{l}\text { Landsat } 1,2 \text {, } \\
3\end{array}$ & MSS & $\begin{array}{l}4 \\
5 \\
6 \\
7 \\
8\end{array}$ & $\begin{array}{l}\text { Green } \\
\text { Red } \\
\text { Near infra red } \\
\text { Near infra red } \\
\text { Thermal }\end{array}$ & $\begin{array}{l}0 / 50-0 / 60 \\
0 / 60-0 / 70 \\
0 / 70-0 / 80 \\
0 / 80-1 / 10 \\
10 / 4-12 / 5\end{array}$ & $\begin{array}{l}79 \\
79 \\
79 \\
79 \\
240\end{array}$ \\
\hline Landsat 4,5 & MSS & $\begin{array}{l}1 \\
2 \\
3 \\
4\end{array}$ & $\begin{array}{l}\text { Green } \\
\text { Red } \\
\text { Near infra red } \\
\text { Near infra red }\end{array}$ & $\begin{array}{l}0 / 50-0 / 60 \\
0 / 60-0 / 70 \\
0 / 70-0 / 80 \\
0 / 80-1 / 10\end{array}$ & $\begin{array}{l}82 \\
82 \\
82 \\
82\end{array}$ \\
\hline Landsat 4, 5 & TM & $\begin{array}{l}1 \\
2 \\
3 \\
4 \\
5\end{array}$ & $\begin{array}{l}\text { Blue } \\
\text { Green } \\
\text { Red } \\
\text { Near infra red } \\
\text { Shortwave infra red } \\
\text { Thermal } \\
\text { Shortwave infra red }\end{array}$ & $\begin{array}{l}0 / 45-0 / 515 \\
0 / 525-0 / 605 \\
0 / 63-0 / 69 \\
075-0 / 90 \\
1 / 55-1 / 75 \\
10 / 4-12 / 5 \\
2 / 09-2 / 35\end{array}$ & $\begin{array}{l}30 \\
30 \\
30 \\
30 \\
30 \\
\\
120 \\
30\end{array}$ \\
\hline Landsat 7 & ETM+ & $\begin{array}{l}1 \\
2 \\
3 \\
4 \\
5 \\
\\
6 \\
7 \\
8\end{array}$ & $\begin{array}{l}\text { Blue } \\
\text { Green } \\
\text { Red } \\
\text { Near infra red } \\
\text { Shortwave infra red } \\
\text { Thermal } \\
\text { Shortwave infra red } \\
\text { Panchromatic }\end{array}$ & $\begin{array}{l}0 / 45-0 / 515 \\
0 / 525-0 / 605 \\
0 / 63-0 / 69 \\
0 / 75-0 / 90 \\
1 / 55-1 / 75 \\
10 / 4-12 / 5 \\
2 / 08-2 / 35 \\
0 / 52-0 / 90\end{array}$ & $\begin{array}{l}30 \\
30 \\
30 \\
30 \\
30 \\
\\
60 \\
30 \\
15\end{array}$ \\
\hline
\end{tabular}

Landsat 8 was launched on February 11, 2013. It is the eighth satellite in the Landsatprogram; the seventh to reach orbit successfully. Originally called the Landsat Data Continuity Mission (LDCM), it is collaboration between NASA and the United States Geological Survey (USGS). Landsat 8 guarantees continuous capturing data and data availability through two sensors, i.e. Operational Land Imager (OLI) and Thermal Infra-Red Sensor (TIRS). These sensors collect imagery data for nine shortwave bands and two thermal wavelengths. It has a design life of 5 years, but carries sufficient fuel for 10 years of operations. The wavelength and spatial resolution of Lnadsat 8 is presented in table 3 [66-89].

Table3: The information related to wavelength and spatial resolution of Landsat 8

\begin{tabular}{|l|l|l|l|l|l|}
\hline Satellite & Sensor & Channel & Band & Wavelength & Spatial resolution (m) \\
\hline Landsat 8 & & 1 & Coastal / Aerosol & $0 / 43-0 / 45$ & 30 \\
& & 2 & Blue & $0 / 45-0 / 51$ & 30 \\
& & 3 & Green & $0 / 53-0 / 59$ & 30 \\
& & 4 & Red & $0 / 64-0 / 67$ & 30 \\
& OLI & 5 & Near infra red & $0 / 85-0 / 88$ & 30 \\
& & 6 & Shortwave infra & $1 / 57-1 / 65$ & 30 \\
& & red & Shortwave infra & $2 / 11-2 / 29$ & 30 \\
& & & red & & \\
& & 8 & Panchromatic & $0 / 50-0 / 68$ & 15 \\
& & 9 & Cirrus & $1 / 36-1 / 38$ & 30 \\
\hline & TIRS & 10 & Thermal & $10 / 60-11 / 19$ & 100 \\
& & 11 & Thermal & $11 / 50-12 / 51$ & 100 \\
\hline
\end{tabular}


In this study, the following satellite data were used to create land cover and land use maps in given time periods. It's better to use the process of land-use changes in short term projects (5-10 years); therefore, keeping that in mind, the satellite images with 13-year intervals were analyzed to reach the research goals.

- Image of ETM+ sensor in Landsat 7, row 35, pass 166, date: 7/8/2002

- Image of OLI_TIRS sensor in Landsat 8, row 35, pass 166, date: 19/8/2015

\subsection{Data Processing}

When the images were uploaded in ENVI software and georeferenced individually, the visual data were ready to process. After conducting the required corrections, the study area was isolated from the images. Now it was time to detect changes of urban land-use through classification.

\subsection{Geometric, Radiometric, Atmospheric Correction}

Preprocessing includes radiometric, geometric and atmospheric corrections. Radiometric correction means calculation of spectral radiance value. To verify the image's geometric accuracy, band 1 was georeferenced to UTM coordinate system- dwg format- by using land-use map of Zanjan city (1:2000); for other bands, the geometric correction was performed in EVNI15.1 software for all images. Then, FLAASH atmospheric correction model was used to relieve atmospheric effects on Lndsat data.

\subsection{Primary Detection of Land-Use Changes}

The color image is created by combining 3 different bands and attributing three main colors- Red, Green, Blue (RGB)- to each band. Otherwise, the image is referred to false color composite (FCC) [90-102].

In FCC, the red is attributed to infrared band, the green to red band and the blue to green band. As result, the vegetation which has the maximum reflection in infrared band is seen in red, the water in blue and soil is seen in grey-brown color. The aim to choose the appropriate bands to create color images is minimization of trivial data and maximum use of crucial information (Pirnazar, Zandkarimi, 2017:113). Figure 2 presents Landsat 7 image of the region with color composite of 2,4,6 and figure 3 illustrates the Landsat 8 image of the same region with color composite of 3,5,7 [103-129].

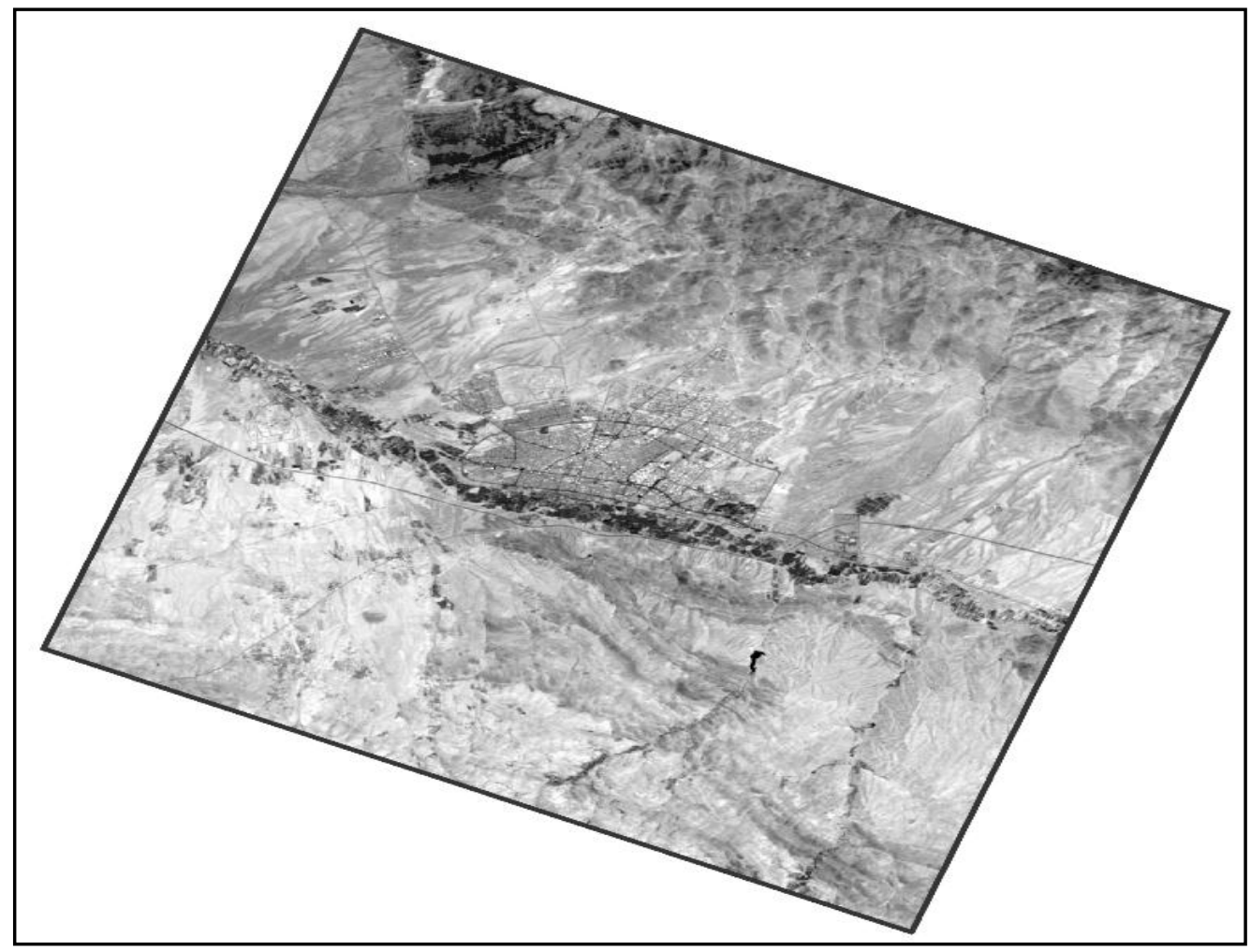

Figure2. False color composite of Zanjan city in 2002 


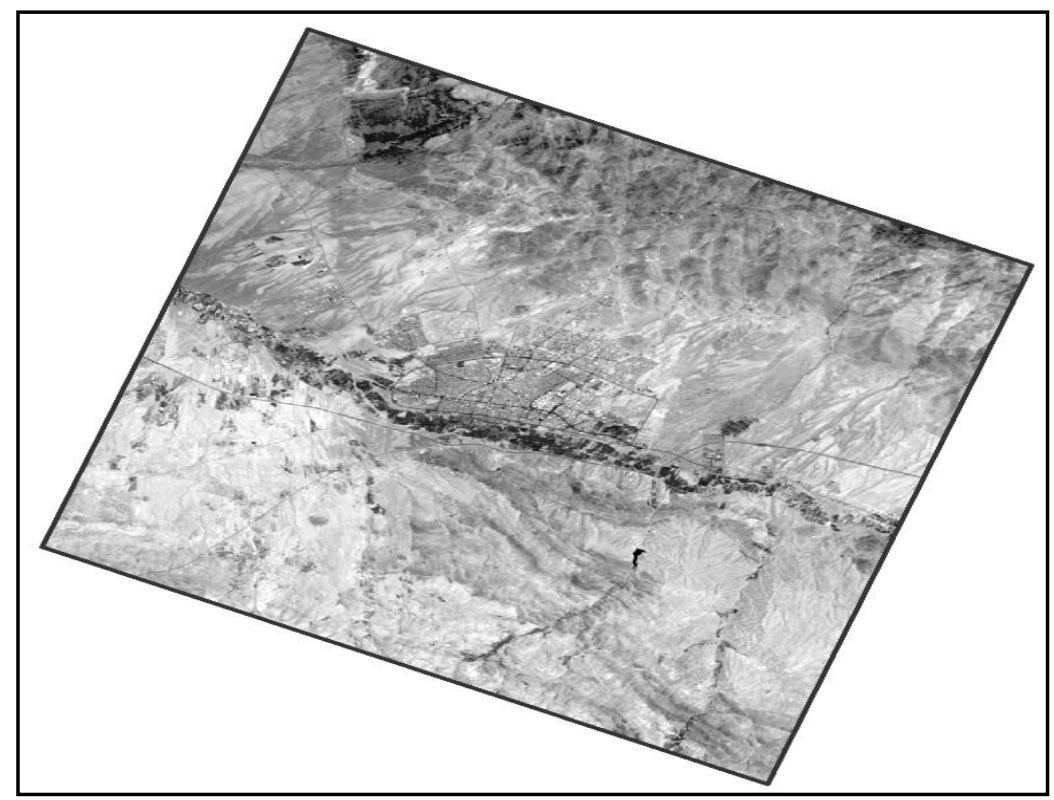

Figure3. False color composite of Zanjan city in 2015

\section{Classification}

Digital classification is relied on spectral differences of various phenomena on different spectral bands (Campbel 2002, Jensen 2005, Mather 2005). However, it doesn't mean that each phenomenon is perfectly divisible on every given band, and thus for this purpose the supervised classification method was chosen. Maximum likelihood algorithm is widely used classification method in most of studies [130-143].

\subsection{Data Collection}

When choosing sampling method, it should be taken into account that only pixels to be selected that are member of a specific class. In addition, the selected pixels should be a comprehensive sample of all pixels belonged to a certain class. It means that the statistical and non-statistical parameters calculated from the sample pixels must be so precise that they could be considered as a relatively accurate estimation of parameters belonging to all pixels in that class. The reference of sampling data should be reliable and compatible with the images were already used. After selecting the training samples, image of Zanjan area was classified to four classes, including:

1. Residential area

2. Road network

3. Vegetation

4. Other regions

Results of image classification and assessment having performed classification, the accuracy of classification was calculated based on reference training regions in ENVI 5.1 software. Table 4 presents overall accuracy and Kappa coefficient for all images.

Table4. Overall accuracy and Kappa coefficient for classified images by maximum likelihood method

\begin{tabular}{|l|l|l|}
\hline Kapa Coefficient & Overall Accuracy & Imagery time \\
\hline $0 / 88$ & $90 / 25$ & $2002 / 08 / 07$ \\
\hline $0 / 90$ & $92 / 05$ & $2015 / 08 / 19$ \\
\hline
\end{tabular}

Overall accuracy reflects overall agreement between two maps throughout the region under a single classification. Normally, the acceptable standard for confidence interval is set to 85 percent of the class (Avery, Berlin 1985). In this study the overall accuracy of classification was above standard level. Kappa coefficient for agreement between two maps was obtained 2. Kappa was used as a given criteria for difference between the maps (reported as overall accuracy) and the likely agreement resulted from the random compatibility between two maps. This index defines a standard for random adaptive assessment [144-159]. 
Change Detection of Urban Land Use and Urban Expansion Using GIS and RS, Case Study: Zanjan Province, Iran

\section{Change Detection}

Change detection operation was performed after image classification and results verification analysis. Change detection is a method used to compare two classified images, in order to make clear that how land-uses are transformed during the interval between two imageries (Shahabi et al, 2009:197). Figure 4 illustrates the change detection of Zanjan land-use using maximum likelihood classifier method.

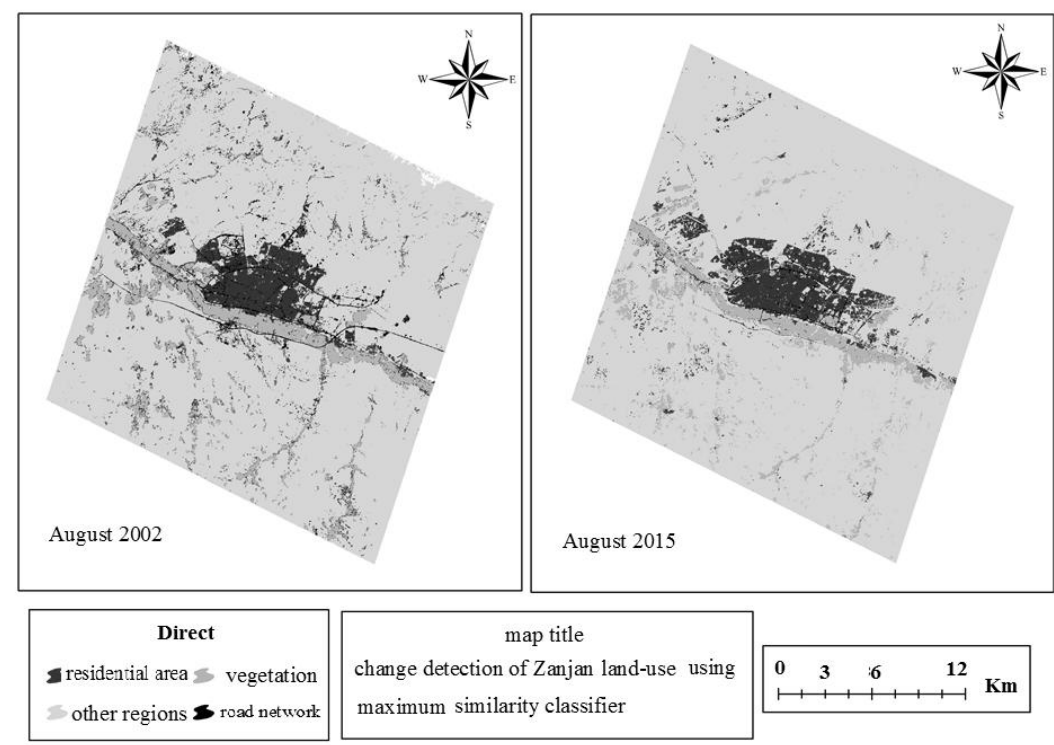

Figure4. Change detection of Zanjan land-use using maximum likelihood classifier method

\subsection{Conclusion}

Immigration and rapid expansion of cities in one hand, and unprecedented destruction of agricultural lands, forests, pastures, etc and their conversion to residential areas on the other hand, are some problems which are seen in different parts of the world. In our country, moreover, severity of these changes is tangible. The analysis of maps and results suggested that the most changes in our study area had been resulted from human activities and conversion of agricultural lands to residential areas. Table 5 presents percent of changes obtained by maximum likelihood classifier method. Figure 5 illustrates land-use changes and expansion of Zanjan City too [160-165].

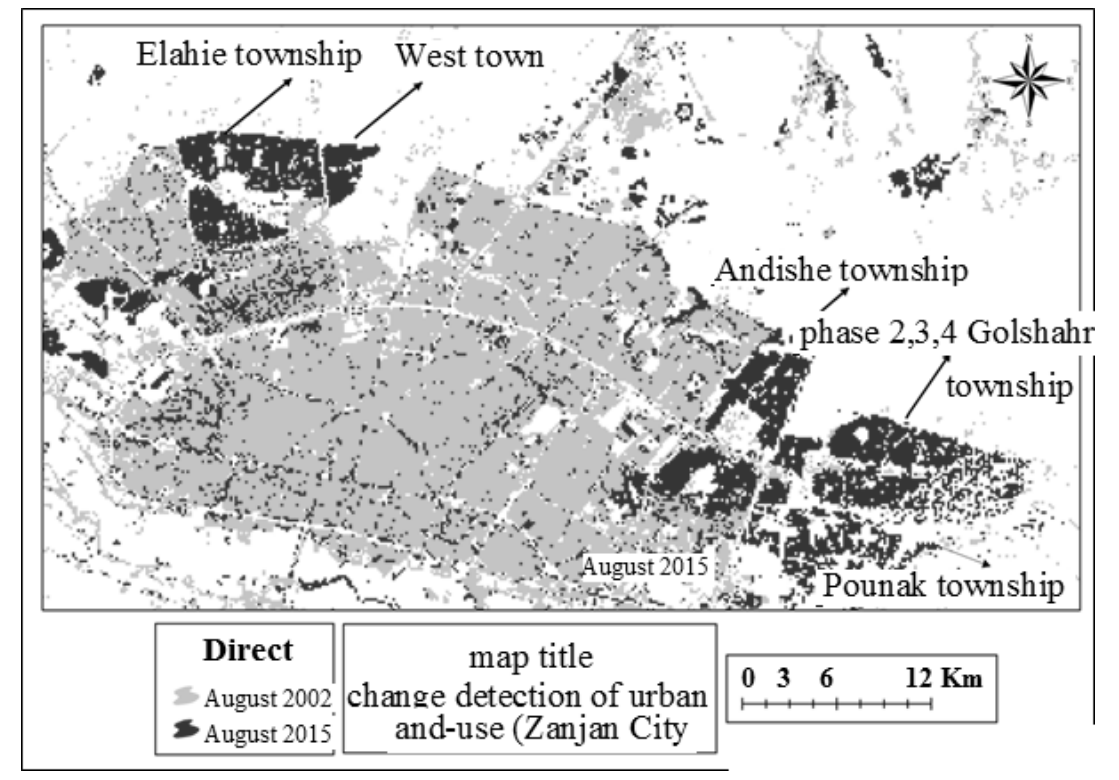

Figure5. Land-use changes and urban expansion of Zanjan city

Table5. Changes obtained from minimum distance classification in terms of percent

\begin{tabular}{|l|l|l|l|l|l|}
\hline Land-use & Residential areas & Road network & Vegetation & Other regions & Sum of class \\
\hline Residential areas & $56 / 951$ & $39 / 678$ & $8 / 29$ & $48 / 394$ & 100 \\
\hline
\end{tabular}


Change Detection of Urban Land Use and Urban Expansion Using GIS and RS, Case Study: Zanjan Province, Iran

\begin{tabular}{|l|l|l|l|l|l|}
\hline Road network & $9 / 828$ & $45 / 434$ & $0 / 465$ & $0 / 917$ & 100 \\
\hline Vegetation & $3 / 569$ & $3 / 818$ & $64 / 07$ & $1 / 263$ & 100 \\
\hline Other regions & $29 / 652$ & $11 / 071$ & $27 / 175$ & $49 / 426$ & 100 \\
\hline Sum of class & 100 & 100 & 100 & 100 & - \\
\hline Changes of class & $43 / 049$ & $54 / 566$ & $35 / 93$ & $50 / 574$ & - \\
\hline
\end{tabular}

\section{REFERENCES}

[1] Ahadnejad Raveshti, Mohsen (2000). 'Land-use changes evaluation and modeling using multi-temporal images and GIS (case study: Maragheh)’ M.Sc thesis; Tehran: Tarbiat Modares University.

[2] Avery, T.E., and Berlin, G.L., (1985). Fundamentals of remote sensing and airphoto interpretation (New York: Macmillan Publishing Company)

[3] Campbell, J. B. (2002). Introduction to remote sensing, Third edition. The Guilford Press, New York. USA, $621 \mathrm{P}$.

[4] Gong, P; (1993) Change Detection U sing principal Component analysis and Fuzzy set theory; Con, j; remote sensing

[5] Pirnazar, Mojtaba; Zandkarimi, Arash (2014). 'Practical guide to ENVI software and satellite image processing' 1st edition, Naghoos publication.

[6] Pirnazar, Mojtaba (2014). 'Identification of urban heat islands and analysis of their spatial relationship with environmental and human factors using remote sensing data (case study: Tehran metropolitan)', M.Sc thesis, Faculty of geography and urban planning, Tabriz University.

[7] Jafari, Mahdi; Ehsani, Amir houshang; Zehtabian, Gholamreza; Nazari, Fahime (2010). 'Change detection of land-use using remote sensing data (case study: Kashan)' 6th national seminar on watershed managemen, Nour, Tarbiat Modares University.

[8] Jalili, Tayebe; Tarahi, Ali Asghar; Delavari, Azad (2013). 'change detection of land use/cover in Zagros forests using satellite images and GIS during 1989-2010 (case study: Dehdez lands)' 1st international conference on IALE, Iran. Isfahan, Isfahan University of Technology.

[9] Jensen, J.R. (2005). Introductory Digital Image Processing: A Remote Sensing Perspective. Englewood Cliffs, NJ: Prentice -Hall. 318p.

[10] Haghighi Khamami, M (2004). 'To analyze different methods for geometric correction of satellite images'. M.s thesis, faculty of natural resources, Someh Sara, Gilan University.

[11] Rabiei, Hamidreza; Ziaian, Parviz; Alimohammadi, Abbas (2004). 'Detection and recovery of land use/cover changes in Isfahan city using remote sensing and GIS'. Human sciences Modares, year 9, No. 4.

[12] Kong, F.N, Nakagoshi, (2004), Spatial-temporal gradient analysis of urban green spaces in Jinan, China,Landscape and Urban Planing,Vol.3.

[13] Kouhkan, Reza (2003). 'Change detection of urban land-use using remote sensing data and GIS (case study: Mashhad)' M.S thesis, Tarbiat Moalem University.

[14] Kavousi Kolahashemi, Hamide; Kheirkhah Zarkesh, Mir Masoud; Almodaresi, Seyed Ali (2013). 'Land use change detection using maximum likelihood classifier method and RS, GIS techniques (case study: Babavali basin, Siahkal)' 1st national seminar on geography, urbanization and sustainable development, Tehran, Koumesh environment, university of areal industry.

[15] Mather, P.M. (2005). Computer processing of remotely-sensed images, Third Edition, John iley and Sons, Ltd, 319p.

[16] Neshat, Abdolhamid (2003). 'Change detection analysis of land use/cover using remote sensing data and GIS in Golestan Province’ M.s thesis, Tehran, Tarbiat Modares University.

[17] Shahabi, Himan; Niazi, Chia; Zoghi, Ayyub; Alimohammadi, Hamze (2009). 'Application of remote sensing and GIS in land-use changes analysis (case study: Saghez county, Kordestan Province)', national seminar on geographical information system (GIS), scientific association for information technology and communication, ministry of defense and armed force logistics.

[18] Ostad-Ali-Askari, K., Shayannejad, M. 2015, Study of sensitivity of Autumnal wheat to under irrigation in Shahrekord, Shahrekord City, Iran. International Journal of Agriculture and Crop Sciences, 8 (4), 602-605.

[19] Shayannejad, M., Akbari, N., Ostad-Ali-Askari, K. 2015, Study of modifications of the river physical specifications on muskingum coefficients, through employment of genetic algorithm. International Journal of Development Research, 5(3), 3782-3785.

[20] Ostad-Ali-Askari, K., Shayannejad, M. 2015, The Reviews of Einstein's Equation of Logarithmic Distribution Platform and the Process of Changes in the Speed Range of the Karkheh River, Khuzestan province, Iran. International Journal of Development Research, 5(3), 3786-3790. 
[21] Ostad-Ali-Askari, K., Shayannejad, M., Ghorbanizadee-Kharazi, H. 2015, Assessment of artificial neural network performance and exponential regression in prediction of effective rainfall, International Journal of Development Research, 5(3),3791-3794.

[22] Shayannejad, M. Akbari, N. and Ostad-Ali-Askari, K. 2015, Determination of the nonlinear Muskingum model coefficients using genetic algorithm and numerical solution of the continuity. Int. J. of Science: Basic and Applied Research, 21(1),1-14.

[23] Ostad-Ali-Askari, K., Shayannejad, M. 2015, The Study of Mixture Design for Foam Bitumen and the Polymeric and Oil Materials Function in Loose Soils Consolidation. Journal of Civil Engineering Research, 5(2), 39-44. DOI: 10.5923/j.jce.20150502.04

[24] Sayedipour, M., Ostad-Ali-Askari, K., Shayannejad, M. 2015, Recovery of Run off of the Sewage Refinery, a Factor for Balancing the Isfahan-Borkhar Plain Water Table in Drought Crisis Situation in Isfahan Province-Iran. American Journal of Environmental Engineering, 5(2): 43-46. DOI: 10.5923/j.ajee.20150502.02

[25] Ostad-Ali-Askari, K., Shayannejad, M. 2015, Developing an Optimal Design Model of Furrow Irrigation Based on the Minimum Cost and Maximum Irrigation Efficiency. International Bulletin of Water Resources \& Development, 3(2), 18-23.

[26] Ostad-Ali-Askari, K., Shayannejad, M. 2015, Presenting a Mathematical Model for Estimating the Deep Percolation Due to Irrigation. International Journal of Hydraulic Engineering, 4(1), 17-21. DOI: 10.5923/j.ijhe.20150401.03.

[27] Ostad-Ali-Askari, K., Shayannejad, M. 2015, Usage of rockfill dams in the HEC-RAS software for the purpose of controlling floods. American Journal of Fluid Dynamics, 5(1), 23-29. DOI: 10.5923/j.ajfd.20150501.03.

[28] Ostad-Ali- Askari, K., Shayannejad, M. 2015, The effect of heterogeneity due to inappropriate tillage on water advance and recession in furrow irrigation. Journal of Agricultural Science, 7(6), 127-136.

[29] Shayannejad, M., Ostad-Ali-Askari, K. 2015, Effects of magnetized municipal effluent on some chemical properties of soil in furrow irrigation. International Journal of Agriculture and Crop Sciences, 8(3), 482489.

[30] Ostad-Ali-Askari, K., Shayannejad, M. 2015, Optimal design of pressurized irrigation laterals installed on sloping land. International Journal of Agriculture and Crop Sciences, ISSN 2227-670X. 8(5), 792-797.

[31] Ostad-Ali-Askari K, Shayannejad M, Eslamian S, Navab-Pour B. 2016, Comparison of solution of SaintVenant equations by characteristics and finite difference methods for unsteady flow analyzing in open channel. International Journal of Hydrology Science and Technology, 6(3), 9-18.

[32] Ostad-Ali-Askari K, Shayannejad M, Eslamian S, et al. 2017, Deficit Irrigation: Optimization Models. Management of Drought and Water Scarcity. Handbook of Drought and Water Scarcity, Taylor \& Francis Publisher, USA. Vol. 3. $1^{\text {th }}$ Edition, pp: 373-389.

[33] Eskandari S, Hoodaji M, Tahmourespour A, Abdollahi A, Mohammadian-Baghi T, Eslamian S, Ostad-AliAskari K. 2017, Bioremediation of Polycyclic Aromatic Hydrocarbons by Bacillus Licheniformis ATHE9 and Bacillus Mojavensis ATHE13 as Newly Strains Isolated from Oil-Contaminated Soil. Journal of Geography, Environment and Earth Science International, 11(2): 1-11.

[34] Shayannejad M, Ostad-Ali-Askari K, Eslamian S, et al. 2017, Development of a new method for determination of infiltration coefficients in furrow irrigation with natural non-uniformity of slope. Sustain. Water Resour. Manag., 3(2): 163-169.

[35] Shojaei N, Shafaei-Bejestan M, Eslamian S, Marani-Barzani M, P. Singh V, Kazemi M, Ostad-Ali-Askari K. 2017, Assessment of Drainage Slope on the Manning Coarseness Coefficient in Mountain Area. International Journal of Constructive Research in Civil Engineering (IJCRCE), 3(1): 33-40.

[36] Bahmanpour H, Awhadi S, Enjili J, Eslamian S, Ostad-Ali-Askari K. 2017, Optimizing Absorbent Bentonite and Evaluation of Contaminants Removal from Petrochemical Industries Wastewater. International Journal of Constructive Research in Civil Engineering (IJCRCE), 3(2): 34-42.

[37] Shayannejad M, Eslamian S, Gandomkar A, Marani-Barzani M, Amoushahi-Khouzani M, Majidifar Z, Rajaei-Rizi F, Kazemi M, P. Singh V, Dehghan SH, Shirvani-Dastgerdi H.R, Norouzi H, Ostad-Ali-Askari K. 2017, A Proper Way to Install Trapezoidal Flumes for Measurements in Furrow Irrigation Systems. International Journal of Research Studies in Agricultural Sciences (IJRSAS), 3(7): 1-5.

[38] Dehghan Sh, Kamaneh S.A.A., Eslamian S, Gandomkar A, Marani-Barzani M, Amoushahi-Khouzani M, Singh V.P., Ostad-Ali-Askari K. 2017, Changes in Temperature and Precipitation with the Analysis of Geomorphic Basin Chaos in Shiraz, Iran. International Journal of Constructive Research in Civil Engineering (IJCRCE), 3(2): 50-57.

[39] Ostad-Ali-Askari K, Shayannejad M. 2016, FLOOD ROUTING IN RIVERS BY MUSKINGUM'S METHOD WITH NEW ADJUSTED COEFFICIENTS. International Water Technology Journal, IWTJ, 6(3): 189-194. 
[40] Godarzi A, Eslamian S, Ostad-Ali-Askari K. Water in Literature Aspects (Social and Cultural Aspects). Publication of Tehran Municipality. First Edition, 2016. ISBN: 978-600-439-096-5. Tehran, Iran.

[41] Ostad-Ali-Askari K, Shayannejad M, Ghorbanizadeh-Kharazi H. 2017, Artificial Neural Network for Modeling Nitrate Pollution of Groundwater in Marginal Area of Zayandeh-rood River, Isfahan, Iran. KSCE Journal of Civil Engineering, 21(1):134-140. Korean Society of Civil Engineers. DOI 10.1007/s12205-016-0572-8.

[42] Shayannejad M, Ostad-Ali-Askari K, Ramesh A, Singh V.P., Eslamian S. 2017, Wastewater and Magnetized Wastewater Effects on Soil Erosion in Furrow Irrigation. International Journal of Research Studies in Agricultural Sciences (IJRSAS), 3(8): 1-14. http://dx.doi.org/10.20431/2454-6224.0308001.

[43] Shayannejad M, Soltani-Toudeshki A.R, Arab M.A, Eslamian S, Amoushahi-Khouzani M, MaraniBarzani M, Ostad-Ali-Askari K. 2017, A Simple Method for Land Grading Computations and its Comparison with Genetic Algorithm (GA) Method. International Journal of Research Studies in Agricultural Sciences (IJRSAS), 3(8): 26-38.

[44] Mohieyimen P, Eslamian S, Ostad-Ali-Askari K, Soltani M. 2017,Climate Variability: Integration of Renewable Energy into Present and Future Energy Systems in Designing Residential Buildings. International journal of Rural Development, Environment and Health Research(IJREH), 1(2): 18-30.

[45] Shayannejad M, Ostad-Ali-Askari K, Eslamian S, et al. 2017, Flow Hydraulic Investigation of the Wastewater on the Soil and Magnetic Field Effects in This Field. International Journal of Constructive Research in Civil Engineering (IJCRCE), 3(3): 1-15.

[46] Shayannejad M, Eslamian S, Singh V.P., Ostad-Ali-Askari K, et al. 2017, Evaluation of Groundwater Quality for Industrial Using GIS in Mountainous Region of Isfahan Province, Koh-Payeh, Isfahan, Iran. International Journal of Constructive Research in Civil Engineering (IJCRCE), 3(3): 24-37.

[47] Eslamian S, P. Singh V, Ostad-Ali-Askari K, R. Dalezios N, Yihdego Y, et al. 2017, Assessment of Aridity Using Geographical Information System in Zayandeh-Roud Basin, Isfahan, Iran. International Journal of Mining Science (IJMS), 3(2): 49-61.

[48] Askari Z, Samadi-Boroujeni H, Fattahi-Nafchi R, Yousefi N, Eslamian S, Ostad-Ali-Askari K, P. Singh V, R. Dalezios N. 2017, Prediction Comparison of Flow Resistance in Channels with Rounded and Angular Coarse Rough Beds. American Research Journal of Civil And Structural, 3(1): 1-15.

[49] Ghane M, Alvankar S.R., Eslamian S, Amoushahi-Khouzani M, Gandomkar A, Zamani E, Marani-Barzani M, Kazemi M, Soltani M, Dehghan SH, P. Singh V, Ostad-Ali-Askari K, HaeriHamedani M, ShirvaniDastgerdi H.R., Zalaki-Badil N. 2017, Sensitivity Analysis of Runoff Model by SWAT to Meteorological Parameters: A Case Study of Kasillian Watershed, Mazandaran, Iran. International Journal of Research Studies in Agricultural Sciences (IJRSAS), 3(10): 1-20.

[50] Shayannejad M, Abedi M.S., Eslamian S, Ostad-AliAskari K, Gandomkar A, Cheng A, et al. 2017, The Contribution of Artificial Charging in Optimal Exploitation of Water Resources, Isfahan, Iran. InternationalJournal of Mining Science (IJMS), 3(3): 9-20.

[51] Eslamian S,Ostad-AliAskari K, et al. 2017, Guidelines to Optimal Design of Furrow Irrigation Based on Plants, Soil and Furrow Specifications. International Journal of Constructive Research in Civil Engineering (IJCRCE), 3(4): 20-39.

[52] Eslamian S, Gandomkar A, Khademolhoseiny A, Ostad-AliAskari K, et al. 2017, The Study on the GeoMorphism Related Characteristics of Shiraz Geomorphic Basin, Fars Province, Iran. International Journal of Mining Science (IJMS), 3(4): 10-23. DOI: http://dx.doi.org/10.20431/2454-9460.0304002.

[53] Matouq, M., Al-Bilbisi, H., El-Hasan, T. and Eslamian, S. 2014, GIS Applications in a Changing Climate, in Handbook of Engineering Hydrology, Ch. 15, Vol. 2: Modeling, Climate Changes and Variability, Ed. By Eslamian, S., Francis and Taylor, CRC Group, USA, 297-312.

[54] Fathian, F., Prasad, A. D., Dehghan, Z.., Eslamian, S., 2015, Influence of land use/land cover change on land surface temperature using RS and GIS techniques, Int. J. Hydrology Science and Technology, Vol. 5, No. 3, 195-207.

[55] Matouq, M., El-Hasan, T., Al-Bilbisi, H., Abdelhadi, M., Hindiyeh, M., Eslamian, S. and S. Duheisat, 2013, The climate change implication on Jordan: A case study using GIS and Artificial Neural Networks for weather forecasting, Journal of Taibah University for Science, Vol. 7, No. 2, 44-55.

[56] Ajigoh, E. and Eslamian, S., 2013, Nyando catchment GIS modeling of flood in undated areas, Journal of Flood Engineering, Vol. 4, No. (1-2), 77-86.

[57] Saatsaz, M., Sulaiman, W.N.A. and S. S. Eslamian, 2011, GIS DRASTIC model for groundwater vulnerability estimation of Astaneh-Kouchesfahan Plain, Northern Iran, International Journalof Water, Vol. 6, No. 1/2, 1-14. 
[58] Kloub, N., Matouq, M., Krishan, M., Eslamian, S. S. and M. Abdelhadi, 2010, Monitoring of Water Resources Degradation at Al-Azraq Oasis, Jordan Using Remote Sensing and GIS Techniques, International Journal of Global Warming, Vol. 2, No. 1, 1-16.

[59] Taheri-Soderjani, H. and Eslamian, S. S., 2016, Determining Evapotranpiration using the GIS and cluster analysis in Isfahan Province, Iran, The Second National Congress on Irrigation and Drainage, August 2325, Isfahan, Iran.

[60] The application of Artificial Neural Network and ArcGIS in groundwater rable simulation of Mahyar plain. Isfahan Province, The Second National Congress on Irrigation and Drainage, August 23-25, Isfahan, Iran.

[61] Eslamian, S, 2015, (ed.) Urban Water Reuse Handbook, Francis and Taylor, CRC Group, USA, 1141 Pages.

[62] Eslamian, S. S., and S. Tarkesh Esfahani, 2011, Water Reuse (Urban Waste Water Application), Arkan Danesh Publishing, Isfahan, Iran, 327 Pages.

[63] Nazif, S. and Tavakolifar, H., Eslamian, S., 2017, Climate Change Impact on Urban Water Deficit, Ch. 5 in Handbook of Drought and Water Scarcity, Vol. 2: Environmental Impacts and Analysis of Drought and Water Scarcity, Ed. by Eslamian S. and Eslamian F., Francis and Taylor, CRC Press, USA, 81-106.

[64] Dayani, S., Sabzalian, M. R., Hadipour, M. Eslamian, S., 2017, Water Scarcity and Sustainable Urban Green Landscape, Ch. 30 in Handbook of Drought and Water Scarcity, Vol. 2: Environmental Impacts and Analysis of Drought and Water Scarcity, Ed. by Eslamian S. and Eslamian F., Francis and Taylor, CRC Press, USA, 557-604.

[65] Bazrkar, M. H., Zamani, N., Eslamian, S., Eslamian, A., Dehghan, Z., 2015, Urbanization and Climate Change, Handbook of Climate Change Adaptation, Ed. By Leal Filho, W., Springer, 619-655.

[66] Chen, Z., Ngo, H. H., Guo,W, and Eslamian, S., 2015, Water Shortages, in Urban Water Reuse Handbook, Ch. 1, Ed. By Eslamian, S., Taylor and Francis, CRC Group, USA, 3-14.

[67] Boogaard, F. and Eslamian, S., 2015, Water Reuse and Sustainable Urban Drainage Systems, in Urban Water Reuse Handbook, Ch. 4, Ed. By Eslamian, S., Taylor and Francis, CRC Group, USA, 37-44.

[68] Shah Naqvi, S. A. A., Sultan, A., and Eslamian, S., 2015, Water Quality Issues in Urban Water, in Urban Water Reuse Handbook, Ch. 8, Ed. By Eslamian, S., Taylor and Francis, CRC Group, USA, 99-112.

[69] Kumar Singh, Ch., Jha, N., and Eslamian, S., 2015, Reuse, Potable Water, and Possibilities, in Urban Water Reuse Handbook, Ch. 9, Ed. By Eslamian, S., Taylor and Francis, CRC Group, USA, 113-126.

[70] Kohansal, M. M., Saadati, S., Tarkesh Esfahany, S., and Eslamian, S., 2015, Urban Water Reuse in Industry, in Urban Water Reuse Handbook, Ch. 11, Ed. By Eslamian, S., Taylor and Francis, CRC Group, USA, 137-148.

[71] Kumar, M., Chidambaram, S., Ramanathan, A. L., Goswami, R., and Eslamian, S., 2015, Criterion, Indices, and Classification of Water Quality and Water Reuse Options, Urban Water Reuse Handbook, Ch. 13, Ed. By Eslamian, S., Taylor and Francis, CRC Group, USA, 163-176.

[72] Eslamian, F., Eslamian, S., and Eslamian, A., 2015, Water Reuse Guidelines for Agriculture, Urban Water Reuse Handbook, Ch. 14, Ed. By Eslamian, S., Taylor and Francis, CRC Group, USA, 177-186.

[73] Eslamian, A., Eslamian, F., and Eslamian, S., 2015, Water Reuse Guidelines for Industry, Urban Water Reuse Handbook, Ch. 15, Ed. By Eslamian, S., Taylor and Francis, CRC Group, USA, 187-194.

[74] Eslamian, S., Eslamian, F., and Eslamian, A., 2015, Water Reuse Guidelines for Recreation, Urban Water Reuse Handbook, Ch. 16, Ed. By Eslamian, S., Taylor and Francis, CRC Group, USA, 195-200.

[75] Banjoko, B. and Eslamian, S., 2015, Environmental Impact Assessment: An Application to Urban Water Reuse, Urban Water Reuse Handbook, Ch. 20, Ed. By Eslamian, S., Taylor and Francis, CRC Group, USA, 229-242.

[76] Amiri, M. J., Eslamian, S., Arshadi, M., and Khozaei, M., 2015, Water Recycling and Community, Urban Water Reuse Handbook, Ch. 22, Ed. By Eslamian, S., Taylor and Francis, CRC Group, USA, 261-274.

[77] Ferdaush, J., Noor Islam, Sh., Reinstädtler, S., and Eslamian, S., 2015, Ethical and Cultural Dimension of Water Reuse, Urban Water Reuse Handbook, Ch. 24, Ed. By Eslamian, S., Taylor and Francis, CRC Group, 285-296.

[78] Bazrkar, M. H., Zamani, N., and Eslamian, S., 2015, Evaluation of Socioeconomic Impacts of Urban Water Reuse Using System Dynamics Approach, Urban Water Reuse Handbook, Ch. 28, Ed. By Eslamian, S., Taylor and Francis, CRC Group, 331-340.

[79] Mujere, N. and Eslamian, S., 2015, Blackwater System, Urban Water Reuse Handbook, Ch. 33, Ed. By Eslamian, S., Taylor and Francis, CRC Group, 393-404.

[80] Abu-Ghunmi, L., and Eslamian, S., 2015, Graywater, Urban Water Reuse Handbook, Ch. 34, Ed. By Eslamian, S., Taylor and Francis, CRC Group, 405-420. 
[81] Eslamian, S., Amininezhad, S. M., and Amininejad, S. M., 2015, Contamination Warning System, Urban Water Reuse Handbook, Ch. 39, Ed. By Eslamian, S., Taylor and Francis, CRC Group, 481-488.

[82] Crusberg, T. C., and Eslamian, S., 2015, Choosing Indicators of Fecal Pollution for Wastewater Reuse Opportunities, Urban Water Reuse Handbook, Ch. 42, Ed. By Eslamian, S., Taylor and Francis, CRC Group, 511-520.

[83] Boogaard, F. and Eslamian, S , 2015, Wastewater Monitoring, Urban Water Reuse Handbook, Ch. 48, Ed. By Eslamian, S., Taylor and Francis, CRC Group, 583-586.

[84] Mujere, N., and Eslamian, S., 2015, Urban Wetland Hydrology and Water Purification, Urban Water Reuse Handbook, Ch. 50, Ed. By Eslamian, S., Taylor and Francis, CRC Group, 603-616.

[85] Nazif, S., and Eslamian , S., 2015, Urban Wetland Hydrology and Changes , Urban Water Reuse Handbook, Ch. 51, Ed. By Eslamian, S., Taylor and Francis, CRC Group, 617-640.

[86] Banjoko, B., and Eslamian, S., 2015, Phytoremediation, Urban Water Reuse Handbook, Ch. 53, Ed. By Eslamian, S., Taylor and Francis, CRC Group, 657-702.

[87] Rivas Hernández, A., Rivas Acosta, I., and Eslamian, S., .2015, Treatment Wetlands: Fundamentals, Urban Water Reuse Handbook, Ch. 54, Ed. By Eslamian, S., Taylor and Francis, CRC Group, 703-716.

[88] Rahman, A., and Eslamian, S., 2015, Rainwater Tanks as a Means of Water Reuse and Conservation in Urban Areas, Urban Water Reuse Handbook, Ch. 60, Ed. By Eslamian, S., Taylor and Francis, CRC Group, 797-808.

[89] Qian, Q., and Eslamian, S., 2015, Groundwater Recharge and Unconventional Water: Design and Management Criteria, Urban Water Reuse Handbook, Ch. 61, Ed. By Eslamian, S., Taylor and Francis, CRC Group, 809-816.

[90] Saket, R. K. and Eslamian, S., 2015, Use of Wastewater for Hydroelectric Power Generation, Urban Water Reuse Handbook, Ch. 63, Ed. By Eslamian, S., Taylor and Francis, CRC Group, 827-838.

[91] Eslamian, S., Amininezhad, S. M., Amininejad, S. M., Adamowski, J., 2015, Application of Nanotechnology in Water Reuse, Urban Water Reuse Handbook, Ch. 64, Ed. By Eslamian, S., Taylor and Francis, CRC Group, 839-844.

[92] Goodarzi, E., Ziaei, L. and Eslamian, S., 2015, Recycled Water in Basin and Farm Scales, Urban Water Reuse Handbook, Ch. 65, Ed. By Eslamian, S., Taylor and Francis, CRC Group, 855-858.

[93] Perez Sierra, J. A. and Eslamian, S., 2015, Water Reuse in Coastal Areas, Urban Water Reuse Handbook, Ch. 67, Ed. By Eslamian, S., Taylor and Francis, CRC Group, 867-874.

[94] Noor Islam, Sh., Reinstädtler, S., and Eslamian, S., 2015, Water Reuse Sustainability in Cold Climate Regions, Urban Water Reuse Handbook, Ch. 68, Ed. By Eslamian, S., Taylor and Francis, CRC Group, 875-886.

[95] Rina, K., Eslamian, S., Tyagi, G., and Singh, N., 2015, Feasibility Studies for Water Reuse Systems, Urban Water Reuse Handbook, Ch. 71, Ed. By Eslamian, S., Taylor and Francis, CRC Group, 909, 926.

[96] Salequzzaman, MD., Tariqul Islam, S. M., Shiddi quzzaman, M., and Eslamian, S., 2015. Climate Change Adaptation and Water Reuse, Urban Water Reuse Handbook, Ch. 75, Ed. By Eslamian, S., Taylor and Francis, CRC Group, 969-980.

[97] Kumar Goyal, M., Singh, V., and Eslamian, S., 2015, Impact of Climate Change on Drinking Water, Urban Water Reuse Handbook, Ch. 76, Ed. By Eslamian, S., Taylor and Francis, CRC Group, 981-1006.

[98] Hamdy, A. and Eslamian, S., 2015, Sustainable Reuse and Recycling of Treated Urban Wastewater, Urban Water Reuse Handbook, Ch. 80, Ed. By Eslamian, S., Taylor and Francis, CRC Group, 1039-1054.

[99] Thakur, J. K., Karmacharya, S., Singh, P., Gurung, D., and Eslamian, S., 2015, Water Reuse Products in Urban Areas, Urban Water Reuse Handbook, Ch. 81, Ed. By Eslamian, S., Taylor and Francis, CRC Group, 1055-1070.

[100]Eslamian, S., Sayahi, M., and Khosravi, B., 2015, Conjunctive Use of Water Reuse and Urban Water, Urban Water Reuse Handbook, Ch. 82, Ed. By Eslamian, S., Taylor and Francis, CRC Group, 1071-1078.

[101] Irfan, Z. B., and Eslamian, S., 2015, Urban Water Reuse Policy, Urban Water Reuse Handbook, Ch. 83, Ed. By Eslamian, S., Taylor and Francis, CRC Group, 1079-1096.

[102] Vafakhah, M., Eslamian, S. and Khosrobeigi Bozchaloei, S., 2014, Low-Flow Hydrology, in Handbook of Engineering Hydrology, Ch. 20, Vol. 1: Fundamentals and Applications, Ed. By Eslamian, S., Francis and Taylor, CRC Group, USA, 433-453.

[103]Cox, J. P., Shaeri Karimi, S. and Eslamian, S., 2014, Optimum Hydrometric Site Selection, in Handbook of Engineering Hydrology, Ch. 22, Vol. 1: Fundamentals and Applications, Ed. By Eslamian, S., Francis and Taylor, CRC Group, USA, 471-483.

[104]Eslamian, S. and Motevallian, S. S., 2014, Sustainability in Urban Water System, in Handbook of Engineering Hydrology, Ch. 27, Vol. 1: Fundamentals and Applications, Ed. By Eslamian, S., Francis and Taylor, CRC Group, USA, 549-562. 
[105]Noor Islam, S., Karim, R., Noor Islam, A., and Eslamian, S., 2014, Wetland Hydrology, in Handbook of Engineering Hydrology, Ch. 29, Vol. 1: Fundamentals and Applications, Ed. By Eslamian, S., Francis and Taylor, CRC Group, USA, 581-605.

[106]Gargouri-Ellouze, E. and Eslamian, S. 2014, Application of Copulas in Hydrology: Geomorphological Instantaneous Unit Hydrograph and Intensity Index of Infiltration Frequency, in Handbook of Engineering Hydrology, Ch. 1, Vol. 2: Modeling, Climate Changes and Variability, Ed. By Eslamian, S., Francis and Taylor, CRC Group, USA, 1-18.

[107]Mujere, N. and Eslamian, S. 2014, Climate Change Impacts on Hydrology and Water Resources, in Handbook of Engineering Hydrology, Ch. 7, Vol. 2: Modeling, Climate Changes and Variability, Ed. By Eslamian, S., Francis and Taylor, CRC Group, USA, 113-126.

[108]Farzaneh, M. R., Eslamian, S. and Mirnezami, S. J. E. 2014, Climate Change: Uncertainty, Impact, and Adaptation, in Handbook of Engineering Hydrology, Ch. 8, Vol. 2: Modeling, Climate Changes and Variability, Ed. By Eslamian, S., Francis and Taylor, CRC Group, USA, 127-146.

[109]Goodarzi, E. and Eslamian, S. 2014, Dam Risk and Uncertainty, in Handbook of Engineering Hydrology, Ch. 9, Vol. 2: Modeling, Climate Changes and Variability, Ed. By Eslamian, S., Francis and Taylor, CRC Group, USA, 147-171.

[110]Fakhri, M., Dokohaki, H., Eslamian, S., Fazeli Farsani, I. and Farzaneh, M. R. 2014, Flow and Sediment Transport Modeling in Rivers, in Handbook of Engineering Hydrology, Ch. 13, Vol. 2: Modeling, Climate

[111] Changes and Variability, Ed. By Eslamian, S., Francis and Taylor, CRC Group, USA, 233-275.

[112]Matouq, M., Al-Bilbisi, H., El-Hasan, T. and Eslamian, S. 2014, GIS Applications in a Changing Climate, in Handbook of Engineering Hydrology, Ch. 15, Vol. 2: Modeling, Climate Changes and Variability, Ed. By Eslamian, S., Francis and Taylor, CRC Group, USA, 297-312.

[113]Noor Islam, S., Gnauck, A., Voigt, H.-J. and Eslamian, S., 2014, Hydrological Changes in Mangrove Ecosystems, in Handbook of Engineering Hydrology, Ch. 18, Vol. 2: Modeling, Climate Changes and Variability, Ed. By Eslamian, S., Francis and Taylor, CRC Group, USA, 353-373.

[114]Kałuża, T. and Eslamian, S. 2014, Impact of the Development of Vegetation on Flow Conditions and Flood Hazards, in Handbook of Engineering Hydrology, Ch. 21, Vol. 2: Modeling, Climate Changes and Variability, Ed. By Eslamian, S., Francis and Taylor, CRC Group, USA, 415-449.

[115]Rahman, A., Haddad, Kh. and Eslamian, S., 2014, Regional Flood Frequency Analysis, 2014, in Handbook of Engineering Hydrology, Ch. 22, Vol. 2: Modeling, Climate Changes and Variability, Ed. By Eslamian, S., Francis and Taylor, CRC Group, USA, 451-469.

[116]Vafakhah, M. and Eslamian, S. 2014, Regionalization of Hydrological Variables, in Handbook of Engineering Hydrology, Ch. 23, Vol. 2: Modeling, Climate Changes and Variability, Ed. By Eslamian, S., Francis and Taylor, CRC Group, USA, 471-499.

[117]Chowdhury, R. K. and Eslamian, S. 2014, Statistical Parameters Used for Assessing Hydrological Regime, in Handbook of Engineering Hydrology, Ch. 26, Vol. 2: Modeling, Climate Changes and Variability, Ed. By Eslamian, S., Francis and Taylor, CRC Group, USA, 537-551.

[118]Mujere, N. and Eslamian, S. 2014, Impact of Urbanization on Runoff Regime, Chowdhury, R. K. and Eslamian, S. 2014, Statistical Parameters Used for Assessing Hydrological Regime, in Handbook of Engineering Hydrology, Ch. 29, Vol. 2: Modeling, Climate Changes and Variability, Ed. By Eslamian, S., Francis and Taylor, CRC Group, USA, 605-615.

[119]Keshavarzy, A., Erskine W. D. and S. S. Eslamian, 1995, River Management Vs. Urban Development In the Hawkesbury-Nepean River Basin, Australia, Regional Conference on Water Resources Management, Isfahan University of Technology, Isfahan, Iran, 629-637.

[120]Eslamian, S. S., Tarkesh-Isfahany, S., 2011, Industrial reuse of urban wastewaters, a step towards sustainable development of water resources, 1st International Conference on Desalination and Environment: A Water Summit, 29 Oct. 1 Nov., Beach Rotana, Abu Dhabi, UAE.

[121]Farzaneh, M. R., Eslamian, S. S. and M. Biabanaki, 2011, The uncertainty impact of multiple linear statistical downscaling model (SDSM) on runoff, 13th Plinius Conference on Mediterranean Storms, Savona, Italy.

[122]Eslamian S. S., Abedi-Koupai, J., Hasheminejad, S. Y., and E. Z. Hosseinipour, 2011, A mathematical model for Ni phyto-extraction from cotaminated soils, 2011 World Environmental and Water Resources Congress: Bearing Knowledge for Sustainability, Palm Springs, USA, 1772-1781.

[123]Rajaei, F., Samadi-Borujeni, H., Eslamian, S. S. and E. Z. Hosseinipour, 2011, The Impact of Artificial Recharge Plans on Aquifer and Demand Management Techniques in Shahrekord, Iran, 2011 World Environmental and Water Resources Congress: Bearing Knowledge for Sustainability, Palm Springs, USA, 833-845. 
[124]Fakhri, M., Farzaneh, M. R., Eslamian, S. S., and E. Z. Hosseinipour, 2011, Uncertainty Analysis of Downscaled Precipitation Using LARS-WG, Statistical Model in Shahrekord Station, Iran, 2011 World Environmental and Water Resources Congress: Bearing Knowledge for Sustainability, Palm Springs, USA, 4572-4578.

[125]Malekian, R., Abedi-Koupai, J. and S. S. Eslamian, 2011, Use of Zeolite and Surfactant Modified Zeolite as Ion Exchangers to Control Nitrate Leaching. International Conference on Environmental Systems Science and Engineering. Venice, Italy.

[126] Amiri, M. J., Eslamian, S.S., Abedi-Koupai, J. and M. Khozaei, 2010, Estimation of daily pan evaporation using the fuzzy regression method in a semi-arid region of Iran, 10th Iranian Conference on Fuzzy Systems, Shahid Beheshti University, Tehran, Iran, July 13-15, 2010. 300-304.

[127]Abedi-Koupai, J., Eslamian S., Gohari A., R. Khodadadi, 2010, The Mechanical Properties of Concrete Containing Nanoparticles of Phoenix Dactilifera, Proceeding of the 3rd Conference on Nanostructures, Kish Island, Iran.

[128]Eslamian, S., Tarkesh-Isfahani, S., Malekpour, I., 2010, Investigating heavy metals concentration of a wastewater treatment plant for agricultural and landscape reuses, Dryland Hydrology: Global Challenges Local Solutions, September 1-4, Westin La Paloma-Tucson, USA.

[129]Abedi-Koupai, J., Eslamian, S. S. and Fakouri, F., 2010, The Effects of Applying Treated Wastewater on the Physical and Mechanical Behavior of Soil-Root Interactions, Geophysical Research Abstracts, Vol. 12, EGU2010-13610, EGU General Assembly, Vienna, Austria.

[130]Eslamian, S. S. and E. Z. Hosseinipour, 2010, A Modified Region of Influence Approach for Flood Regionalization, 2010 World Water and Environmental Resources Congress, Providence, Rhode Island, USA.

[131] Moravejolahkami, B. and S. S. Eslamian, 2010, Application of Two-Step And FAO-56 Evapotranspiration Models In An Arid Environment, IWA World Water Congress and Exhibition, Montreal, Canada.

[132]Hassanzadeh, H, Eslamian, S. S., Abdolhosseini, M and S. Grimaldi, 2010, Application of L-moments for Estimation of Quantile Mixtures, International Workshop on Advances in Statistical hydrology, Taormina, Italy.

[133]Mirabbasi, R. and S. S. Eslamian, 2010, Delineation of Groundwater Quality Concerning Applicability of Pressure Irrigation System In Sirjan Watershed, Iran, International Conference on Management of Soil and Groundwater Salinization in Arid Regions, Sultan Qaboos University, Muscat, Oman.

[134]Malekian, R., Abedi-Koupai, J. and S. S. Eslamian, 2010, An Effective Method to Reduce Groundwater Pollution in Farmlands, The 1st Annual Conference- Ibb 2010, Environmental Science and Technology, Republic of Yemen.

[135]Malekian, R., Abedi-Koupai, J. and S. S. Eslamian, 2010, The Effect of Ionic Strength on the Ammonium Adsorption and Desorption by Semnan Clinoptilolite Zeolite. Iran International Zeolite Conference, Tehran, Iran.

[136]Moravejalahkami, B., Mostafazadeh-Fard, B., Heidarpour, M., Abbasi, F., Eslamian, S. S. and E.VazquezFernandez, 2010, The effects of variable inflow hydrographs on water saving in furrow irrigation using zero-inertia model, International Conference on Environmental Science and Technology, Bangkok, Thailand.

[137]Abedi-Koupai, J., Ghaheri, E., Eslamian, S., 2009, The Effects of Superabsorbent Polymer and Irrigation Regime on Phytoremediation of Petroleum Contaminated Soils, 9th International Seminar on Polymer Science and Technology, Iran Polymer and Petrochemical Institute, Tehran, Iran.

[138]Eslamian, S. S., Hedayat, E. and S. Tarkesh Esfahani, 2009, Reusing Reclaimed Wastewater through Artificial Recharge for Increasing Sustainable Water, First Conference of Water Resources Management, Shahroud, Iran.

[139]Eslamian, S. S., M. J. Amiri and W. Balderer, 2009, A Review on Thermal Spring in Iran, Groundwater, Thermal and Mineral Water in Areas of Arid Conditions: Consequences for the Current Situation of Climate Change and the Increasing Population of Egypt, IAH-CMTW Workshop, Cairo, Egypt.

[140]Eslamian, S. S., Khordadi, M. J., Baba Ahmadi, A. and J. Abedi-Koupai, 2009, Effects of Variations In Climate Parameters on Evapotranspiration In the Arid and Semiarid Regions, RCM2009, Lund University, Sweden.

[141]Eslamian, S. S., Hasanzadeh, H. and J. Abedi-Koupai, 2009, Drought Index Frequency Analysis Using LMoments, Managing Water in a Changing World, Torino, Italy, July 27-31.

[142]Eslamian, S. S. and H. Hasanzadeh, 2009, Climate Change Impact on Frequency Analysis of Wind Speed, IAMAS2009, 19-29 July, Montreal, Canada. 
[143]Eslamian, S. S. and S. A. Gohari, 2006, Investigation of Flooding Process in South-Esfahan Basin, International Congress of Islamic World Geographers, Esfahan University, Isfahan.

[144]Eslamian, S. S., 2006, Detection of Hydrologic Changes, International Symposium on Drylands Ecology and Human Security, Dubai, United Arab Emirates.

[145]Eslamian, S. S., Ghoudarzi, A. and R. Nazari, 2006, Investigation of the Changes of Permeability, Physical and Chemical Characteristics of Sediment Basins for Artificial Recharge In Bagh-E-Sorkh Region, Shahreza, Isfahan, 22nd Annual International Conference on Soils, Sediments and Water, University of Massachusetts at Amherst, USA.

[146]Abedi-Koupai, J., Eslamian, S. S., Salehi, M. and J. Khajehali, 2006, Effect of Water Stress on Population Changes of Emp on Cowpea, 8th European Congress of Entomology, Izmir, Turkey.

[147]Saadati, S., Soltani-Koupai, S. and S. S. Eslamian, 2006, Frequency Analysis of Meteorological Drought Using Standard Precipitation Index (SPI) In Zayanderud Basin, First Regional Conference on Optimum Utilization of Water Resources in the Karun and Zayanderud Rivers Basins, Shahrekord University, 167.

[148]Eslamian, S. S., Abedi Koupai, J., A. Godarzi, 2005, The Impact of Artificial Recharge on Yield of Baghsorkh Ganat, Shahreza, Second International Conference on Ganat, Yazd.

[149]Biabanaki M. and S. S. Eslamian, 2005, Comparing Regional Flood and Low Flow Frequency by Index Flood and Hybrid Methods, International Conference on Human Impacts on Soils Quality Attributes in Arid \& Semiarid Regions, Isfahan University of Technology, Esfahan, Iran.

[150]Biabanaki M. and S. S. Eslamian, 2005, Monthly Flow Forecasting by Time Series Models In Ghezelozen River, Iran-Korea Climate Modeling Workshop, Mashhad, Iran.

[151]Soltani, S., Modarres R. and S. S. Eslamian, 2005, The Determination of Regional Rainfall Climates of Iran Based on Time Series Modeling, Iran-Korea Climate Modeling Workshop, Mashhad, Iran.

[152]Eslamian S. S., 2004, Evaporation Modeling for Some Dam Reservoirs In Iran, Western Pacific Geophysics Meeting, Hawaii Convention Center, Honolula, Hawaii.

[153]Eslamian S. S., Sattari M. T. and R. Nazari, 2004, Optimization and Simulation of Water Distribution In Small Multi-Reservoir System, Sixth International Conference on Hydro-science and Engineering, Brisbane, Australia.

[154]Chavoshi, S. and S. Eslamian. 2004. Regional flood frequency analysis using L-moments. International Conference on Hydrology: Science and Practice for the 21st Century, London, England.

[155]Chavoshi, S. and S. Eslamian. 2004. Study on hydrological homogeneity of the catchments (a case study: North Karoon / Iran). International Conference on Hydrology: Science and Practice for the 21st Century, London, England.

[156]Eslamian, S. S., Tabatabaei H., Abedi Koupaei, J. and R. Nazari, 2003, A Mathematical and Management Model of Groundwater With Emphasis on Artificial Recharge for Damaneh Plain, Isfahan Province of Iran, The Second International Conference on Salt Water Intrusion and Coastal Aquifers, Merida, Mexico.

[157]Eslamian, S. S., Khatoonabadi, S. A., Shahidi Hamadani, A. and R. Nazari, 2003, Water Resources Mismanagement and Desertification of a Semiarid Region, Gahavand Plain, Seventh International Conference on Dry Land Development: Sustainable Development of Dry Lands in the 21st Century, The International Dry Lands Development Commission (IDDC), Tehran, Iran.

[158]Eslamian, S. S. and M. Afyuni, 2003, Investigating Nitrate Contamination In the Groundwater of Isfahan Plain, Iran, 5th International Congress of Turkish Society of Toxicology, Antalya, Turkey.

[159]Eslamian, S. S. and R. Nazari, 2003, Hydrological Homogeneity Test of Catchments In Central Part of Iran Using L-Moments Diagram, The International Conference on the Rational Use and Construction of Water Resources in a Changing Environment, Yerevan, Armenia.

[160]Sattari, M. T., Eslamian, S. S. and A. Abrishamchi, 2003, Optimization of Water Consumption In a 9Reservoir River System, 6th International Conference on Civil Engineering, Isfahan University of Technology, Iran.

[161]Modarres, R. and S. S. Eslamian, 2003, Drought Frequency Analysis Using Markov Chain for Isfahan City, Third Regional Conference and First National Conference on Climate Change, University of Isfahan, Isfahan, Iran.

[162]Nosrati, K., Mohseni Saravi, M., Eslamian S. S., Sharifi F. and M. Mahdavi, 2003, Identification of Homogeneous Regions In Hydrological Drought Using Multivariate Statistical Techniques In Arid and Semi-Arid Zones, Third Regional Conference and First National conference on Climate Change, University of Isfahan, Isfahan, Iran.

[163]Eslamian, S. S. and Y. Osroosh, 2002, The Impact of Dam Construction of Climate Parameters, Third Regional Conference and First National conference on Climate Change, University of Isfahan, Isfahan, Iran. 
[164]Eslamian, S. S. and R. Nazari, 2002, Economic Evaluation of an Iranian Water Resources Project, Third Conference on Agriculture and Natural Resources, Iran and Russia, Moscow.

[165]Eslamian, S. S., Khajedin, S. J. and A. Amiri-Maleki, 2002, Role of dam construction in developing desert regions of arid zone climates, 8th International Conference on Understanding Future Dryland environmental Changes From Past Dynamics, Yazd University, Iran.

[166]Eslamian, S. S., Ashtari A. and R. Nazari, 2002, A Traditional System of Water Harvesting, Turkey Nest, International Conference of Human and Water, Ramsar, Iran.

[167]Chavoshi, S. and S. Eslamian, 2001, The role of traditional utilization of water in management of water resources of arid land, Second Regional Conference on Water and Wastewater Management in Asia, Tehran, Iran.

[168]Gazavi, R. and S. Eslamian, 2006, Runoff in an Iranian Karstic Watershed as Compared with a Neighbor non-Karstic Watershed, 8th Conference on Limestone Hydrogeology, Neuchâtel, Switzerland.

[169]Chavoshi-Boroujeni, S. and S. S. Eslamian, 2000, The Role of Combining Traditional (Ganat) and Conventional (Artificial Recharge) Systems on Economic-Social Development of Baghsorkh Region, Shahreza, First International Conference on Ganat, Yazd Regional Water Board, Iran.

[170]Taebi, A., Eslamian, S. S. and M. Vashtani, 1999, Evaluation of Urban Runoff Quality Models, First Regional Conference on Water Balance, Khuzestan Water and Power Authority, Ahwaz, Iran, 393-402.

[171]Eslamian, S. S. and, S. Chavoshi. 1999. Comparison of regression and hybrid models of flood frequency analysis, First Regional Conference on Water Balance, Khuzestan Water and Power Authority, Ahwaz, Iran.

[172]Chavoshi, S., S. Eslamian. 1999. Catchments group delineation using different methods of homogeneity. Proceeding of the First Regional Conference on Water Balance, Ministry of Energy of Iran, Bureau of Water and Energy of Khoozestan, Ahvaz, Iran.

[173]Eslamian, S. S., 1995, What Can Be Measured After the Occurrence of a Flood, Regional Conference on Water Resources Management, Isfahan University of Technology, Isfahan, Iran, 397-403.

[174] Keshavarzy, A., Erskine W. D. and S. S. Eslamian, 1995, River Management Vs. Urban Development In the Hawkesbury-Nepean River Basin, Australia, Regional Conference on Water Resources Management, Isfahan University of Technology, Isfahan, Iran, 629-637.

[175]Nazemosadat, M. J., Cordery I. and S. S. Eslamian, 1995, The Impacts of Persian Gulf Sea Surface Temperatures on Iranian Rainfall, Regional Conference on Water Resources Management, Isfahan University of Technology, Isfahan, Iran, 809-818.

[176]Eslamian S. S., 1992, Regionalization of Flood Frequency Estimation, First Seminar for Iranian Students Studying in Australia, University of New South Wales, Sydney, Australia.

[177]Zareian, M. J., Eslamian, S. S., and Safavi, H. R. 2016, Investigating the Effects of Sustainability of Climate Change on the Agriculture Water Consumption in the Zayandeh-Rud River Basin, Water and Soil Sci., Vol. 20, No. 75, 113-128.

[178]Salarian, M., Najafi, M., Larijani, Sh. and S. S. Eslamian, 2016, The Potential Evapotranspiration Trends in Isfahan and Rasht Stations, Extension and Development of Watershed Management, Vol. 4, No. 13, 4152.

[179]Dehghan, Z., Fathian F., and S. Eslamian, 2015, Comparative Assessment of SDSM, IDW and LARS-WG Models for Simulation and Downscaling of Temperature and Precipitation, Journal of Water and Soil, Vol. 29, No. 5, 1376-1390.

[180]Malekian, R., Abedi-Koupai, J. and S. S. Eslamian, 2014, Estimating Parameters of LEACHN in ZeoliteAmended Soil and Unamended-Soil Conditions, JWSS-Isfahan University of Technology, Vol. 18, No. 68, 197-210.

[181]Abedi-Koupai, J, Salehi-Sirzar, M., Eslamian, S. S., Khajeali, J., Y. Hosseini, 2014, Effect of Water and Pests Stresses on Cowpea Yield, JWSS-Isfahan University of Technology, Vol. 18, No. 68, 157-171.

[182]Salarian, M., Najafi, M., Davari, K., Eslamiyan, S. S., Heidari, M., 2014, The most Appropriate Method to Estimate Potential Evapotranspiration in Meteorological Data Scarce Condition in the Warm and Cold Months of the Year (Case Study of Isfahan), Iranian Journal of irrigation and Drainage, No. 1, Vol. 8, 6273.

Citation: Dr. Kaveh Ostad-Ali-Askari et.al. (2018) Change Detection of Urban Land Use and Urban Expansion Using GIS and RS, Case Study: Zanjan Province, Iran, International Journal of Constructive Research in Civil Engineering, 4(1), pp.23-38. DOI: http://dx.doi.org/10.20431/2454-8693.0401003

Copyright: (C) 2018 Dr. Kaveh Ostad-Ali-Askari, This is an open-access article distributed under the terms of the Creative Commons Attribution License, which permits unrestricted use, distribution, and reproduction in any medium, provided the original author and source are credited. 